\title{
JAPANESE LEARNING AT SMA NEGERI 30 JAKARTA (Ethnography Research)
}

\section{Christofeira Zita Karundeng $^{1}$, Sri Harini Ekowati ${ }^{2}$ Darmahusni $^{3}$ Universitas Negeri Jakarta}

christofeirazita_pb15s2@mahasiswa.unj.ac.id ${ }^{1}$, sriharini@unj.ac.id ${ }^{2}$, darmahusni@unj.ac.id ${ }^{3}$

\begin{abstract}
This research is aimed to get a deep understanding towards Japanese learning in 30 Senior High School in Jakarta. This research uses qualitative approach with ethnography method. The data was gained from observation, interview, field note and documentation right from the location of the research. The source of research to get the data is from Japanese teacher and all things related with the process of Japanese learning. The teacher and students play an important role during the process of learning. The results of the research are: 1) The four objectives which need to be achieved in Japanese learning are : listening skill (choukai), speaking (kaiwa), reading (dokkai), and writing (sakubun) and so that the students have selling point when they are about to work. 2) The curriculum being used is 2013 curriculum. 3) The teaching material being used by the teacher is adjusted with the text book which is sakura book, supporting book and the syllabus. 4) the teaching strategy and the method is lecturing, exercises, assignments based on theme. 5) media used such as tapes, picture cards, learning CD, japanesse language and culture DVD. 6) evaluation of processes and outcomes.
\end{abstract}

\section{Keywords : Japanese learning, qualitative and ethnography}

Language has a very important role that enables people understand information, express their feelings, develop their knowledge and technology, and culture. It shows that language is a main tool for people communicate both written and spoken language. Therefore, learning foreign languages, such as Japanese language, is very important.

According to Dale, learning is an enduring change in behavior, or in the capacity to behave in a given fashion, which results from practice or other forms of experience. It means that learning is a permanent change or an enduring change in behavior or capacity to behave as the results from practice or past experience or on-going experience (Dale, 2012: 3).

Japanese language is the most common language used as a means for a Japanese native to communicate and interact with others. The language is also used by Japanese people who live outside Japan for work or other reasons. Besides, it is also used by people who have learnt it.

Okuda in Sudjianto divides the learners in nihongo kyouiku into two types. The ffirst is the learners who learn Japanese language in Japan as a foreign or second language. The second one is people who learn Japanese outside Japan as a foreign language or national language (Sudjianto, $2010: 13$ ).

Learning a foreign language, especially Japanese language, helps learners to develop their communication skills, both written and spoken language. Therefore, English is not the only language that must be taught in schools but also Japanese language. It is worth to teach 
and, improve learners' knowledge so they are able to use technology, become a creative and smart, and have the identity of Indonesia.

Japanese language is really unique, and able to attract the interest of foreigner learning Japanese language. To learn Japanese language, a competence standardd is required to achieve. It includes four skills; listening (choukai), speaking (kaiwa), reading (dokkai), dan writing (sakubun). According to the data taken from The Japan Foundation, numbers or Japanese learners outside Japan increased, as shown below. (Japan Fondation : 2015)

Figure 1. Increasing numbers of Japanese Learners outside Japan

\begin{tabular}{|l|l|l|}
\hline No & Year & $\begin{array}{l}\text { Number of } \\
\text { Learners }\end{array}$ \\
\hline 1 & 1979 & 127.167 \\
\hline 2 & 1984 & 584.932 \\
\hline 3 & 1988 & 733.802 \\
\hline 4 & 1990 & 981.407 \\
\hline 5 & 1993 & 1.623 .455 \\
\hline 6 & 1998 & 1.102 .103 \\
\hline 7 & 2003 & 2.356 .745 \\
\hline 8 & 2006 & 2.979 .820 \\
\hline 9 & 2009 & 3.651 .232 \\
\hline 10 & 2012 & 3.985 .669 \\
\hline 11 & 2015 & 3.655 .024 \\
\hline
\end{tabular}

In spite of communication using Japanese language as the effect of the increasing numbers of Japanese learners, Japanese culture cannot be separated from the trends happening in teenagers from primary to high school levels, even university students, such as manga, attract Indonesian citizens to learn Japanese. In addition to that, The Japan Foundation that has strategic place in the city centre, was built by the government to develop the quality of Japanese language education in Indonesia following the national curriculum of Indonesia.

Japanese culture in Indonesia such as Japanese drama, anime, manga, music, harajuku style and also cosplay has aroused a lot of interests and even produced new talents for the learners to learn Japanese language and culture. SMA Negeri 30 has a Japan Club as one of extracurricular activities for students. It is known as Nihon Kazoku (Japanese Family), and guided by Doreyati-sensei, their Japanese teacher. Students in the club do not only learn Japanese language, such as the grammar, and reading, but also Japanese lifestyle, and many kinds of Japanese culture both the traditional and modern one.

Lustyantie (2015) in the IJLECR journal with the title "“"Morality in cultural elements in fairytale and its implication in learning french as foreign language", this research focuses on moral as a cultural element that exists in fairy tales and its implications in learning French as a foreign language or a second language. The difference with the research conducted by researchers is that the research conducted is is seeing Japanese language learning from processes and cultures that are running and developing while Lustyantie's research focuses on learning French. Equally, both of these studies find out language learning by looking at the cultural elements in it. 
A previous study is done by Iriany about English language learning for Second Grade students of SDSD Pondok Kelapa 03 Pagi, East Jakarta. It is a qualitative study using an ethnographic method. The study shows that teacher is able to create a positive learning environment to maximize the learning process. The objective of learning English of this study is to develop English skills based on context, condition and students daily life.

Based on the initial observation done at SMA Negeri 30, East Jakarta, learning process in this school has a unique concept. Teacher delivers the lesson in an easy and fun way. It is understandable by the students so that they are able to apply what they have been learnt in their daily life or school context, for example, ohayou gozaimasu, sensei (Good morning, Ms/Mr), arigatou gozaimasu (thank you).

Learning Japanese language at SMA Negeri 30 is fun, either conducted in the classroom or outside the classroom. Teacher assigned students to list down verbs, nouns, adjectives in Japanese language when watching Japanese drama or anime. Besides students were asked to create a short conversation using the sentence structure that has been taught in the classroom. For those reasons, the researcher chose SMA Negeri 30, Jakarta for conducting her research.

SMA Negeri 30 also actively participated for Japanese Festival called "Bunkasai", which is held every year by schools or universities in Jakarta. Students may join a quiz contest, reading competition (dokkai), writing hiragana, katakana or kanji and cosplay competition. Furthermore, SMA Negeri 30 has supporting facilities, such as, Language Lab, various kinds of media for learning, and teachers who are actively participated in Japanese Language Teachers Meeting (MGMP Bahasa Jepang) and also students with good achievement in Japanese language learning.

Japanese language learning at SMA Negeri 30 is also supported by the extracurricular activities. The activities are arranged according to the school curriculum. Students develop their knowledge, interests and skills through the extracurricular activities. The process of Japanese language learning runs smoothly without any distractions, as the activities are planned by the teachers. Moreover, the extracurricular activities of Japanese language at SMA Negeri 30 Jakarta plays a big role to increase students' creativity and intelligence.

Based on the previous explanations, the focus of this study is the learning process of Japanese language learning of for XI grade students at SMA Negeri 30. The deeper study has been done to gain more understanding about the learning process of Japanese language learning, with the sub focus as followed: 1) the objectives of Japanese language, 2) curriculum/syllabus used, 3) learning materials, 4) teaching methods and strategies used in Japanese language learning, 5) teaching media 6) evaluation in language learning 7) cultural themes in Japanese language learning at SMA Negeri 30, Jakarta.

\section{METHODS}

The study used qualitative approach with ethnographic as research method. Ethnography is a process where the researcher is engaged in the research. This study describes and learns values, characters and language of a particular community. Besides, the researcher has to collect data using the interview, observation, note-taking and documentation. 
Spradley states that ethnography is a work describing a particular culture. The aim of ethnography is to understand ways of life from the people's perspectives and their relationship with life and realize their vision about the world (Spradley, 1980).

The data is gathered from Japanese language teachers, principal, students at SMA Negeri 30, and from other documents related to Japanese language learning. Observation data is obtained from direct observation of Japanese language learning process of students at SMA Negeri 30, Jakarta, either in the classroom or outside the classroom. Meanwhile, interviews data is collected from the results of discussions and interactions with Japanese language teachers. Furthermore, documentation data is collected from related documents of Japanese language learning, for examples, Japanese language curriculum, syllabus, lesson plan, and other Japanese textbooks used by both teacher and students.

Moreover, the data analysis for this study uses Spradley ways; 1) domain analysis, 2) taxonomy analysis, 3) componential analysis, 4) theme analysis. The data is validated by doing credibility test using extended observation, constant observation, triangulation, and peer discussion.

\section{RESULTS AND DISCUSSION}

Below are the findings and discussions of the study. The findings and discussion were guided by sub-focus presented in the previous chapter and based on the observations, documentation, research note, and interviews.

\section{a. The Aim of Japanese Language Learning}

From the observations and interviews, the aim of Japanese language learning in SMA Negeri 30, Jakarta are 1) enable students to master four language skills; listening (choukai), speaking (kaiwa), reading (dokkai), dan writing (sakubun), 2) have more values by having more language skills for their future work.

The aim is set based on the existing curriculum. Students are expected to be able both spoken and written language in any kind of situations, formal or informal, using simple language, so that they are able to communicate by mastering four basic language skills; listening (choukai), speaking (kaiwa), reading (dokkai), dan writing (sakubun), and also gain more knowledge.

According to the aim above, Japanese language learning at SMA Negeri 30 is conducted with developing the four skills but it is set based on the lesson theme and time allocation. Learning process at school will run smoothly with the presence of active, creative, fun, and innovative Japanese language teachers. This motivates and make students have more interests learning Japanese language.

\section{b. Japanese Language Curriculum}

SMA Negeri 30 uses Kurikulum 2013 for the Japanese language lesson. It was implemented in SMA Negeri 30, since 2014. The implementation of Kurikulum 2013 guide students to be active in finding information related to the theme that they are going to learn. Kurikulum 2013 is the national curriculum used in Indonesian education system now. It is a fixed curriculum implemented by the government replacing Kurikulum 2006 or is often called Kurikulum Tingkat Satuan Pendidikan (KTSP). 
Moreover, from the interviews with Japanese language teachers, the implementation of Kurikulum 2013 is more appropriate with the learning proces at SMA Negeri 30, Jakarta. Syllabus and lesson plan of Japanese language learning at SMA Negeri 30 are designed and composed in line with Kurikulum 2013, and based on students' needs.

\section{c. Japanese Language Learning Materials}

Learning materials are the main resources for Japanese language teaching and learning. They make the Japanese language teaching and learning easier both in the classroom and outside classroom, in individual or group. When presenting the learning materials, the teacher selects the materials according to her students' skills, then sets the goal based on Kurikulum 2013.

Japanese language learning materials used in SMA Negeri 30 are;

1) Japanese Language Textbook Sakura Jilid I, II, dan III terbitan The Japan Fondation Jakarta, 2) Japanese Language Textbook Nihongo I dan II published by The Japan Foundation Jakarta, 3) Other supporting book, for instance, vocabulary books, letters book/goi, reading comprehension books/dokkai, and listening books/choukai, 4) Recorded audio and video as the supporting language learning materials of Japanese culture such as life and school in Japan, Japanese songs, and recorded of pronunciation, sentences, and conversations, 5) Picture Flash cards for letters, nouns, adjectives and verbs used according to the materials from The Japan Foundation.

\section{d. Japanese Language Learning Methods}

Methods and strategies for language learning are needed for teachers in order to achieve the learning objectives. They are also needed for Japanese language learning at SMA Negeri 30 Jakarta. The method is used as a tool for presenting the materials. The approach used in this method is adjusted with Kurikulum 2013. Students are expected to master four skills; listening, speaking, reading, and writing. Therefore, every teacher must have the ability to select the most appropriate learning strategy for the different kinds of learning.

The whole learning process at SMA Negeri 30, Jakarta used communicative approach. However, it should be matched with syllabus and lesson plan. The basic of the communicative approach is students' needs and language function that aims at enabling students to communicate in real situation. Communicative approach is based on students' participations to find out what they want to learn through their learning experiences.

The teacher also used various teaching methods. Story telling method was used when she explained the reading materials (dokkai) since the teacher needed enough time to explain difficult materials which are related to grammatical structure (bunpou) and vocabulary (goi). Teacher explained and asked questions to students about materials that students have been learnt in the textbook. The purpose of this activity is to develop and explore students' knowledge and understanding of the text.

In learning activities, listening (choukai), writing (sakubun), speaking (kaiwa), the method being used is drilling method. Students are asked to listen to vocabulary and dialogue for several times. After that, students were asked to listen to the vocabulary and dialogue that are played several times. Then, they were told to repeat the words, while teacher paid attention to their pronunciation. Afterward, teacher asked students to write down several vocabularies and dialogues in the conversations. Next, they were asked to make their own conversation in Japanese language individually and group, and practiced their conversation in 
front the classroom. This kind of activity is really helpful for students to be able to practice writing hiragana, katakana, even kanji in order to make students easier to understand to oral text read by the teacher or CD.

\section{e. Instructional Media for Japanese Language Learning}

Media for foreign language learning including Japanese language is needed as one of the learning components. As using media for learning activities is very important, every teacher has to know the advantages of using media in Japanese language and other foreign language learning. Facilities are also connected with media for language learning.

Other supporting facilities for Japanese language learning at SMA Negeri 30, Jakarta, for example Language Lab, has LCD and speaker that are often used for listening and writing. Besides, there is a library providing Japanese textbooks and books about Japanese culture which give advantages for the students learning Japanese language. The school also has a room for s extracurricular activities. For media, using for Japanese language learning in the classroom, teacher uses various kinds of media; provided by the school or media made by the teacher.

Media is used to improve students' skills so that students understand learning materials and motivate students to learn. They are flash cards ( $e$-ka-do / 絵カード), letter cards, power point, cassettes, and CD for Japanese language learning, DVD for learning Japanese culture and film (drama and animation).

Media is the most important resource for as helping tools to deliver the materials to students. In conclusion, the function of media is to support the achievement of learning objectives at school. Besides, using the media is hoped to make learning environment become more condusive, fun, active and creative. Media for language learning is something that cannot be separated from Japanese language learning because it raises students' interest and students' motivation to accomplish the learning objectives of Japanese language learning.

\section{f. Evaluation of Japanese Language Learning}

Evaluation is definitely done for language learning. In Japanese language learning, there are two aspects of assessment; process evaluation and results. In process evaluation, students participations are seen from the beginning of the lesson to the end. Meanwhile, result evaluation can be measured from quiz, class test, mid semester test, final test and also practical test. The evaluation is based on the four basic language skills; listening (choukai), speaking (kaiwa), reading (dokkai), and writing (hyouki and sakubun). It is done in order to see the students' improvement to achieve the set objectives.

Evaluation in Japanese language leaning can be assessed from three aspects; 1) cognitive, 2) psychomotor, 3) affective. The evaluation can be done at the end of the learning process are group assignment, class test, and summative test.

\section{CONCLUSIONS}

Based on findings, the conclusion of Japanese language learning in SMA Negeri 30 Jakarta can be made, as follows: 
The objective of Japanese language learning is to communicate both verbal and nonverbal in any kind of situations, either formal or informal, using simple language. Therefore, students are proficient in four basic language skills; listening (choukai), speaking (kaiwa), reading (dokkai), and writing (hyouki, sakubun), and also gain knowledge about Japan.

Kurikulum 2013 is really approriate to be used in SMA Negeri 30, Jakarta. Syllabus and lesson plan of Japanese language learning are designed based on Kurikulum 2013 and students' needs. For learning materials, teacher selects the materials first according to students' needs, then set the learning objectives based on Kurikulum 2013. The learning materials are taken from Sakura book, other Japanese language text book, and/or also recorded audio or video.

Meanwhile, teaching methos are used as tools or ways for presenting the materials. The methods should be fit with Kurikulum 2013, in which students must be proficient in four skills: listening, speaking, reading, and writing. The approach used for Japanese language learning is the communicative approach in order to engage students to be more active and creative. Meanwhile, the role of teacher is as a facilitator.

Media for language learning is the main resource to present the learning materials to students. Media is used to help teacher delivering the materials. In conclusion, the important function of media is to support the achievement of leaning goals. Various kinds of media are used for language learning, such as, flash cards (e-ka-do / 絵カード), letter cards, power point, cassettes, and CD for Japanese language learning, DVD and other media.

For evaluation of language learning, can be seen from the language activities: students engagement in the class and final score of daily test, written test, practical test.

Overall, it can be concluded that learning process for Japanese language learning in the class or outside the class depends on the media, methods, materials, and others. But the most important thing is the learning process will run smoothly if there is interaction between teachers and students.

\section{REFERENCES}

Japan Fondation. (2015). Present Condition of Overseas Japanese Language Education Survey Report on Japanese Language Education Abroad. Tokyo: The Japan Fondation.

Lustyantie Ninuk. (2015). Morality in cultural elements in fairytale and its implication in learning french as foreign language. Intenational Journal Of Language Education and Cultural review.

Schunk Dale H. (2012). Learning Theories An Educational Perspective. Boston New york: Pearson.

Spradley James P. (2010). Participant Observation Harcourt Brace Jovanovich College.

Sudjianto. (2010), Metodologi Pembelajaran Keterampilan Berbahasa Jepang. Jakarta: Kesaint Blanc. 